\title{
Consumption of oat bran enriched extruded flakes and its effect on biomarkers of hyperlipidemia and elevated blood pressure
}

\author{
Hina Hafeez ${ }^{1}$, Beenish Israr ${ }^{2 *}$, Masood Sadiq Butt ${ }^{1}$ and Syeda Nimra \\ $\mathrm{Naqvi}^{3}$ \\ 1. National Institute of Food Science and Technology, University of Agriculture, Faisalabad-Pakistan \\ 2. Institute of Home Sciences, University of Agriculture, Faisalabad-Pakistan \\ 3. Institute of Diet and Nutritional Sciences, University of Lahore, Islamabad Campus, Islamabad-Pakistan \\ *Corresponding author's email: beenish_israr@hotmail.com \\ Citation \\ Hina Hafeez, Beenish Israr, Masood Sadiq Butt and Syeda Nimra Naqvi. Consumption of oat bran enriched \\ extruded flakes and its effect on biomarkers of hyperlipidemia and elevated blood pressure. Pure and Applied \\ Biology.Vol. 9, Issue 2, pp1334-1340. http://dx.doi.org/10.19045/bspab.2020.90139
}

\begin{tabular}{llll}
\hline \hline Received: 06/11/2019 & Revised: 20/01/2020 & Accepted: 06/02/2020 & Online First: 24/02/2020 \\
\hline \hline
\end{tabular}

\section{Abstract}

Oat is an imperative cereal grain added into products for increasing fiber content. Oat bran fiber has property to combat oxidative stress and reduce the level of low-density lipoprotein as well as boosting up high-density lipoprotein indirectly. Present study was planned to analyze the proximate composition, minerals and sensory evaluation of oat bran enriched extruded flakes prepared after using different amount of oat and wheat. Intervention trial consisting of 30 days was done. Twenty test subjects (20) having elevated blood pressure and lipid profile were recruited and divided into two groups according to treatments. Group-1 kept as control and Group-2 given oat bran enriched extruded flakes. Current study showed that oat bran enriched extruded flakes contain an appreciable amount of fiber $17.2 \pm 0.08 \%$, fat $4.9 \pm 0.1 \%$, carbohydrate $52.9 \pm 2.45$, protein $12.9 \pm 0.6 \%$, sodium $22.1 \pm 0.1$ $\mathrm{mg} / 100 \mathrm{~g}$ and potassium $374.67 \pm 4.5 \mathrm{mg} / 100 \mathrm{~g}$. On the other hand, significant decrease was $(p<0.001)$ found in systolic and diastolic blood pressure of treatment group $(150 \pm 9.4-127 \pm 6.7 \mathrm{mmHg}, 100 \pm 8.8$ $84.5 \pm 8.0 \mathrm{mmHg}$ ). Whereas, negative control group with treatment of oat bran flakes with zero percent of oat bran showed non-significant result in systolic and diastolic blood pressure. Moreover, oat bran flakes also showed $(p<0.001)$ reduction in lipid profile including $7.4 \%$ decrease in blood cholesterol, $14.3 \%$ increment in high-density lipoprotein, 3.5\% reduction in low-density lipoprotein and 7.3\% decrease in triglycerides. Thus, present study concluded that oat bran has nutritional potential to reduce blood pressure as well as biomarkers of lipid profile.

Keywords: Blood pressure; Extruded flakes; Oat bran

\section{Introduction}

Cereal based products have been considered as integral part of human diet for many years. It contributes $50 \%$ of dietary fiber as part of regular diet in various countries [1].
Basically, dietary fiber is termed as analogous carbohydrate that showed resistant to digestion and absorption in small intestine. Dietary fiber reduces contact of food with digestive enzyme. It also prevents absorption 
of bile in small intestine. That results increased the usage of cholesterol for bile acid synthesis. Moreover, it has been reported that supplementation of fiber not only lowers the intake of energy but also slow down digestion which results improved absorption of different dietary nutrients and ultimately reduces risk factors for atherosclerosis [2]. High consumption of whole grain is associated to reduce risk of several diseases like cardiovascular diseases, hypertension, obesity and type-2 diabetes [3]. Oat is usually consumed as whole grain and its bran is used in different food products including breakfast cereals, bread and infant foods due to its nutritional profile. Oat bran is major byproduct of husk oat that is obtained after processing. It contains high amount of vitamin, minerals, protein and soluble fiber termed as $\beta$-glucan. Fiber utilization of oat bran is better than other cereal crops due to presence of soluble fiber. The $\beta$-glucan is an active component of oat bran that exhibits antidiabetic as well as cholesterol lowering property [4]. Consumption of oat-based products has been reported to reduce serum cholesterol, decrease blood glucose as well as plasma insulin response [5]. Moreover, oat bran is termed as lipid lowering agent. As presence of soluble fiber has been reported to bind with intestinal cholesterol. This binding further prevents digestion and metabolism of cholesterol. It reduces risk of hypercholesteremia in latter stage [6].

Oat bran has been reported to enhance gut health due to their fermentable and watersoluble properties of dietary fiber. Thus, it produces almost double SCFAs (short chain fatty acids) as compared to wheat bran after improving proliferation of beneficial bacteria in large intestine [7].

Main purpose of present study was to investigate effect of oat bran enriched flakes against risk factors of cardiovascular disease including hypertension and hyperlipidemia.

\section{Materials and methods \\ Procurement of Raw Materials}

Oat (A.Sativa) and wheat (T.Aestivum) were purchased from the local market of Faisalabad. One batch of each cereal crop was purchased for sample preparation and analysis. Oat and wheat bran were prepared after passing through processing in Quaderumate Senior Mill (Brabender-102. D.9302).

\section{Milling}

The milling process of oats comprised of three steps such as, cleaning, sizing and dehulling. Food sample i.e., oat was cleaned to expel tidy debris and rocks belong to different grains. After this, then dehulled after passing through the dehuller. The inner groats of oat were separated from outer huller. Groats were taken and passed through further processing such as grinding and sieving. Oat bran was isolated at this point from flour after a few granulating and sieving operations.

\section{Preparation of extruded flakes}

After milling, flakes were prepared by using twin screw extruders (Model NoSYSLG30VI) followed by prepared mixture [8]. Composite flour was made after using different percentages of oat and wheat (Table 1). Flakes were extruded at moisture content $16 \%$, temperature $120^{\circ} \mathrm{C}$ and $265 \mathrm{rpm}$ screw speed. Wheat and oat bran composite flour was taken and $60 \mathrm{ml}$ water was added. Mixture was kept for 5 minutes. Then, $5 \mathrm{ml}$ oil and 2-5 drops of color was added. Mixing was done for $10 \mathrm{~min}$. Rest time (30 minutes) given to the preparation. Finally, extruder was started until required temperature was obtained. Sample was put into extruder (hopper) and final product was collected into food grade stainless steel bin. Extruded flakes were cooled down at room temperature and stored in polyethylene bags.

\section{Proximate composition of extruded flakes}

Proximate analysis including moisture, crude fat, ash, fiber, crude protein and Nitrogen Free Extract were performed in laboratory of food 
science at National Institute of Food Science and technology (NIFSAT), University of Agriculture, Faisalabad according to their respective methods mentioned in previous study [9].

Extruded flakes were dried in hot air oven for moisture determination. Muffle furnace was used for making of ash followed by agitation of food sample. Protein content was estimated by Kjeldhal's method. Crude fat was done by refluxing sample along with ether in Soxhlet apparatus. However, crude fiber estimation involves digestion of fat free sample with $1.25 \% \mathrm{H}_{2} \mathrm{SO}_{4}$ and $1.25 \% \mathrm{NaOH}$ solution followed by agitation via muffle furnace [10].

Table 1. Composition of treatment plan for extruded flakes

\begin{tabular}{|c|c|c|}
\hline \multirow{2}{*}{ Treatments } & \multicolumn{2}{|c|}{ Composition of extruded flakes } \\
\cline { 2 - 3 } & Oat (\%) & Wheat (\%) \\
\hline $\mathrm{T}_{0}$ & 0 & 100 \\
\hline $\mathrm{T}_{1}$ & 5 & 95 \\
\hline $\mathrm{T}_{2}$ & 15 & 85 \\
\hline $\mathrm{T}_{3}$ & 25 & 75 \\
\hline
\end{tabular}

\section{Mineral analysis}

Mineral analysis including sodium $(\mathrm{Na})$ and potassium $(\mathrm{K})$ were done by using atomic absorption spectrophotometer (Hitachi AAS,Z-8200,Japan) followed by wet digestion method as described previously [10].

Sensory Evaluation: Sensory attributes of oat bran enriched extruded flakes was done by the technique used previously [11]. Group of 10 judges including students and teaching faculty participated in the study. Oat bran enriched flakes were evaluated for color, crispiness, taste, texture and overall acceptability on a hedonic scale in sensory evaluation laboratory at NIFSAT.

\section{Efficacy Study}

\section{Ethical Approval}

Current study was approved ethically by the Institutional Biosafety Committee (IBC) of University of Agriculture, Faisalabad. All information regarding the study was explained to all the participants and written informed consent was also signed from each participant prior to intervention.

\section{Test subjects}

20 adults (10 men and 10 women) with disturbed lipid profile and high blood pressure were selected for clinical trial.
During study trial, control and treatment diet was given to all the participants for 30 days.

\section{Study design}

For randomized case control study, test subjects were randomly selected and divided into two groups i.e., Group-A and Group-B. Group-A was kept control, provided with flakes that contain only wheat $\left(\mathrm{T}_{0}\right)$ and Group-B was served with $\mathrm{T}_{2}$ (15\% Oat; $85 \%$ Wheat) i.e., best acceptable treatment selected on the basis of sensory evaluation. Blood samples of the study participants were taken to determine the blood lipid profile of subjects at baseline, 15 and 30 day of the study.

\section{Biochemical tests}

Biochemical tests including lipid profile along with following tests were done to check effect of treatments on test subjects.

\section{i. Total cholesterol}

CHOD-PAP method was used to measure cholesterol level followed the procedure of [12].

\section{ii. High and low-density lipoprotein}

Measurement of high-density lipoprotein (HDL) and low-density lipoproteins (LDL) in serum was done [13]. 


\section{iii. Triglycerides}

Triglycerides in serummeasured by fluid triglycerides (GPO-PAP) procedure as clarified by [14].

\section{iv. Measurement of blood pressure}

Blood pressure was measured by using a standardized mercury sphygmomanometer at the start, mid and end of study [15].

\section{Statistical analysis}

Data of proximate analysis, minerals and lipid profile were subjected for statistical analysis and results were shown as Mean \pm Standard Deviation (SD). Moreover, regression analysis was done to check regression as coefficient $\left(\mathrm{R}_{2}\right)$. Analysis of variance (ANOVA) was used to check significant difference among treatments by software of statistics 8.1 [16].

\section{Results and discussion}

Proximate composition and mineral analysis of extruded flakes

In present study, proximate composition of oat bran flakes with different percentages of wheat and oat bran is presented in (Table 2). Results showed that treatment-3 $\left(\mathrm{T}_{3}\right)$ has highest moisture content $(9.1 \pm 0.57 \%)$, crude protein $(12.9 \pm 0.6 \%)$, fat $(5.3 \pm 0.32 \%)$, fiber $(23.2 \pm 0.9 \%)$ and ash $(3.3 \pm 0.06 \%)$ along with high profile of minerals including potassium $(391.0 \pm 2.64 \mathrm{mg} / 100 \mathrm{~g})$ and sodium $(22.9 \pm 0.1 \mathrm{mg} / 100 \mathrm{~g})$. However, treatment 0 $\left(\mathrm{T}_{0}\right)$ showed least nutrient profile as compared to rest of treatments. Nutritional profile of oat grain is reported to contain protein $13 \%$, ash $3.1 \%$, fiber $10.3 \%$ and fat $7.5 \%[17]$.

Table 2. Proximate composition $(\%)$ and mineral $(\mathrm{mg} / 100 \mathrm{~g})$ level in oat bran enriched extruded flakes (Means \pm SE)

\begin{tabular}{|c|c|c|c|c|c|}
\hline $\begin{array}{c}\text { Sr. } \\
\text { No. }\end{array}$ & Nutritional Components & $\begin{array}{c}\text { Treatment-0 } \\
\left(\mathbf{T}_{\mathbf{0}}\right)\end{array}$ & $\begin{array}{c}\text { Treatment-1 } \\
\left(\mathbf{T}_{\mathbf{1}}\right)\end{array}$ & $\begin{array}{c}\text { Treatment-2 } \\
\left(\mathbf{T}_{\mathbf{2}}\right)\end{array}$ & $\begin{array}{c}\text { Treatment-3 } \\
\left(\mathbf{T}_{\mathbf{3}}\right)\end{array}$ \\
\hline 1 & Crude protein & $10.8 \pm 0.3$ & $11.0 \pm 0.5$ & $12.9 \pm 0.60$ & $14.3 \pm 0.15$ \\
\hline 2 & Crude fat & $4.3 \pm 0.56$ & $4.6 \pm 0.11$ & $4.9 \pm 0.10$ & $5.3 \pm 0.32$ \\
\hline 3 & Crude fiber & $8.2 \pm 0.1$ & $11.2 \pm 0.05$ & $17.2 \pm 0.08$ & $23.2 \pm 0.9$ \\
\hline 4 & Ash & $2.7 \pm 0.01$ & $2.9 \pm 0.05$ & $3.1 \pm 0.06$ & $3.3 \pm 0.06$ \\
\hline 5 & Nitrogen free extract & $65.2 \pm 2.50$ & $61.4 \pm 2.50$ & $52.9 \pm 2.45$ & $44.8 \pm 2.43$ \\
\hline 6 & Moisture & $8.8 \pm 0.57$ & $8.9 \pm 0.57$ & $9.0 \pm 0.1$ & $9.1 \pm 0.57$ \\
\hline 7 & Potassium $(\mathrm{mg} / 100 \mathrm{~g})$ & $327.33 \pm 3.05$ & $364.00 \pm 3.60$ & $374.67 \pm 4.50$ & $391.00 \pm 2.64$ \\
\hline 8 & Sodium $(\mathrm{mg} / 100 \mathrm{~g})$ & $20.5 \pm 0.35$ & $21.7 \pm 0.2$ & $22.1 \pm 0.1$ & $22.9 \pm 0.1$ \\
\hline
\end{tabular}

\section{Sensory evaluation of extruded flakes}

Sensory evaluation for extruded flakes were done after using different composition of oat and wheat. Table 3 showed overall acceptability including color, flavor, taste, texture and crispiness for treatment-2 $\left(\mathrm{T}_{2}\right)$. Data showed that treatment-2 $\left(\mathrm{T}_{2}\right)$ have highest value of color $(6.8 \pm 0.57)$, flavor $(7.9 \pm 0.67), \quad$ taste $(8.8 \pm 1.03), \quad$ texture (8.3 \pm 0.7$)$, crispiness $(7.4 \pm 0.6)$ and overall acceptability (7.6 00.69$)$. Thus, on the basis of hedonic scale results, treatment- $2\left(\mathrm{~T}_{2}\right)$ was found to be highly acceptable for intervention trial of test subjects. Moreover, oat-based breakfast cereals were also reported to be highly acceptable and commonly consumed due to their different sensory characteristics [18].

Lipid profile after intake of extruded flakes

Intake of oat bran enriched extruded flakes showed significant reduction in lipid profile. Present study (Table 4) showed that lipid profile including cholesterol showed gradual decrease from day-0 to day-30 after intake of treatment-2.Cholestrol was found to be $254.50 \pm 3.02$ to $249.50 \pm 3.02$ from 0 to 30 days after treatment $-2\left(\mathrm{~T}_{2}\right)$.On the other hand, treatment- 0 showed no change in cholesterol level at the end of the study.Treatment-2 
contains high amount of oat bran and oat bran is reported to lower lipid profile due to presence of soluble fiber i.e., $\beta$-glucan. Moreover, Oat bran fiber increases the absorption of bile in small intestine and cholesterol in blood makes more bile salts to reabsorb bile. That will ultimately lower cholesterol level [19].

Table 3. Sensory evaluation of oat bran enriched extruded flakes (Means \pm SE)

\begin{tabular}{|c|c|c|c|c|c|}
\hline $\begin{array}{c}\text { Sr. } \\
\text { No. }\end{array}$ & Characteristics & $\begin{array}{c}\text { Treatment-0 } \\
\left(\mathbf{T}_{\mathbf{0}}\right)\end{array}$ & $\begin{array}{c}\text { Treatment-1 } \\
\left(\mathbf{T}_{\mathbf{1}}\right)\end{array}$ & $\begin{array}{c}\text { Treatment-2 } \\
\left(\mathbf{T}_{\mathbf{2}}\right)\end{array}$ & Treatment-3 $\left.\mathbf{( T}_{\mathbf{3}}\right)$ \\
\hline 1 & Color & $5.9 \pm 1.15^{\mathrm{a}}$ & $5.4 \pm 0.63^{\mathrm{a}}$ & $6.8 \pm 0.57^{\mathrm{c}}$ & $4.3 \pm 1.15^{\mathrm{a}}$ \\
\hline 2 & Flavor & $6.4 \pm 0.96^{\mathrm{b}}$ & $5.7 \pm 0.81^{\mathrm{a}}$ & $7.9 \pm 0.67^{\mathrm{b}}$ & $4.9 \pm 0.51^{\mathrm{a}}$ \\
\hline 3 & Taste & $7.50 \pm 0.85^{\mathrm{c}}$ & $5.7 \pm 0.75^{\mathrm{a}}$ & $8.8 \pm 1.03^{\mathrm{a}}$ & $5.2 \pm 0.9^{\mathrm{b}}$ \\
\hline 4 & Texture & $6.6 \pm 0.7^{\mathrm{b}}$ & $6.1 \pm 0.7^{\mathrm{b}}$ & $8.30 \pm 0.7^{\mathrm{a}}$ & $5.10 \pm 0.6^{\mathrm{b}}$ \\
\hline 5 & Crispiness & $6.3 \pm 0.8^{\mathrm{b}}$ & $5.5 \pm 0.8^{\mathrm{c}}$ & $7.4 \pm 0.6^{\mathrm{b}}$ & $5.0 \pm 0.7^{\mathrm{b}}$ \\
\hline 6 & $\begin{array}{c}\text { Overall } \\
\text { Acceptability }\end{array}$ & $6.3 \pm 0.78$ & $5.6 \pm 0.51$ & $7.6 \pm 0.69$ & $4.8 \pm 0.82$ \\
\hline
\end{tabular}

Results are presented as mean $\pm \mathrm{SE}(\mathrm{n}=20)$; means followed by superscript letters are significantly different $(\mathrm{p}<0.05)$. Hedonic rating, $1=$ dislike extremely, $9=$ like extremely

Table 4. Intake of Oat Bran Enriched Extruded Flakes and its effect on biomarker of Hyperlipidemia and Elevated Blood Pressure

\begin{tabular}{|c|c|c|c|c|}
\hline Lipid Profile (mg/dl) & Treatment- $0\left(\mathbf{T}_{0}\right)$ & p-value & Treatment-2 $\left(\mathrm{T}_{2}\right)$ & p-value \\
\hline \multicolumn{5}{|c|}{$\begin{array}{c}\text { Cholesterol } \\
\end{array}$} \\
\hline At base line & $256.4 \pm 3.02$ & $\geq 0.005$ & $254.5 \pm 3.02$ & $<0.001$ \\
\hline After 15 days & $254.4 \pm 3.02$ & $\geq 0.005$ & $242.5 \pm 3.02$ & $<0.001$ \\
\hline After 30 days & $252.4 \pm 3.02$ & $\geq 0.005$ & $235.5 \pm 3.02$ & $<0.001$ \\
\hline \multicolumn{5}{|c|}{ LDL } \\
\hline At base line & $192.4 \pm 2.0$ & $\geq 0.005$ & $193.2 \pm 3.8$ & $<0.001$ \\
\hline After 15 days & $190.4 \pm 2.0$ & $\geq 0.005$ & $190.2 \pm 2.7$ & $<0.001$ \\
\hline After 30 days & $189.2 \pm 2.2$ & $\geq 0.005$ & $186.3 \pm 2.7$ & $<0.001$ \\
\hline \multicolumn{5}{|c|}{ HDL } \\
\hline At base line & $38.4 \pm 9.4$ & $\geq 0.005$ & $38.4 \pm 9.4$ & $<0.001$ \\
\hline After 15 days & $36.4 \pm 9.4$ & $\geq 0.005$ & $40.5 \pm 9.4$ & $<0.001$ \\
\hline After 30 days & $34.5 \pm 9.4$ & $\geq 0.005$ & $43.9 \pm 9.4$ & $<0.001$ \\
\hline \multicolumn{5}{|c|}{$\begin{array}{c}\text { Triglycerides } \\
\end{array}$} \\
\hline At base line & $204.5 \pm 3.0$ & $\geq 0.005$ & $204.9 \pm 3.1$ & $<0.001$ \\
\hline After 15 days & $202.3 \pm 3.2$ & $\geq 0.005$ & $196.3 \pm 3.1$ & $<0.001$ \\
\hline After 30 days & $201.3 \pm 3.2$ & $\geq 0.005$ & $189.8 \pm 3.0$ & $<0.001$ \\
\hline \multicolumn{5}{|c|}{ Systolic blood pressure $(\mathrm{mmHg} \pm \mathrm{SD})$} \\
\hline At base line & $145 \pm 10.8$ & $\geq 0.005$ & $150 \pm 9.4$ & $<0.001$ \\
\hline After 15 days & $142 \pm 10.8$ & $\geq 0.005$ & $135 \pm 6.7$ & $<0.001$ \\
\hline After 30 days & $140 \pm 10.7$ & $\geq 0.005$ & $127 \pm 6.7$ & $<0.001$ \\
\hline \multicolumn{5}{|c|}{ Diastolic blood pressure (mmHg \pm SD) } \\
\hline At base line & $110 \pm 8.8$ & $\geq 0.005$ & $100 \pm 8.8$ & $<0.001$ \\
\hline After 15 days & $100 \pm 8.8$ & $\geq 0.005$ & $91 \pm 8.8$ & $<0.001$ \\
\hline After 30 days & $100 \pm 8.8$ & $\geq 0.005$ & $84.5 \pm 8.0$ & $<0.001$ \\
\hline
\end{tabular}

On the other hand, high-density lipoprotein after intake of treatment- $0\left(\mathrm{~T}_{0}\right)$ showed non- significant $\quad(\mathrm{p}-\geq 0.005) \quad$ effect. Whereas, treatment-2 showed high level of HDL i.e., 
$38.4 \pm 9.4$ to $43.5 \pm 9.4$ from day-0 to day- 30 . Moreover, results were found to be significant ( $\mathrm{p}$-value $\leq 0.001$ ) that showed reduce risk of cardiovascular disease after intake of treatment-2. High level of HDL is considered as factor that play a considerable role in lipid profile as well as lesser the threat of heart disease [20].

Low-density lipoprotein, in negative control group exhibited no impact on LDL level (p$>0.005)$. Treatment-2 $\left(\mathrm{T}_{2}\right)$ showed significant decline $(\mathrm{p}-<0.001)$ in LDL level. Thus, reduction in LDL level has positive effect including decrease of cardiovascular risk factors and also act as biomarker of hyperlipidemia. Oat grain consumption is also reported to reduce LDL level [20]. Thus, present study results correlate with past studies.

Triglyceride level was recorded as $204.50 \pm 3.0$ at 0 day. On the other hand, it was found to be $204.30 \pm 3.2$ after intake of treatment -0 and reduced to $189.8 \pm 3.0$ after intake of treatment- 2 at the end of study i.e. day-30.

\section{Intervention trial against hypertension}

Intake of oat bran enriched extruded flakes for control of blood pressure showed significant decrease in systolic and diastolic blood pressure. Data illustrated in (Table 4) showed significant $(\mathrm{p}<0.001)$ reduction in systolic blood pressure (150 \pm 9.4 to $127 \pm 6.9 \mathrm{mmHg}$ ) and diastolic blood pressure (100 \pm 8.8 to $84.5 \pm 8 \mathrm{mmHg}$ ) after treatment2. However, Treatment-0 showed nonsignificant effect in systolic and diastolic blood pressure. Moreover, Intake of oat bran flakes has been reported to lower systolic and diastolic blood pressure in hypertensive test subjects due to presence of soluble fiber termed as $\beta$-glucan [15].

\section{Conclusion}

Present study reported that oat bran enriched extruded flakes are rich in fiber, protein and micronutrients like sodium and potassium. Presence of high proportion of oat in extruded flakes exhibited reductive as well as therapeutic effect against hypertension and lipid profile.

\section{Authors' contributions}

Conceived and designed the experiments: B Israr \& MS Butt, Performed the experiments: H Hafeez \& SN Naqvi, Analyzed the data: H Hafeez \& SN Naqvi, Contributed materials/ analysis/ tools: H Hafeez \& SN Naqvi, Wrote the paper: B Israr, H Hafeez \& SN Naqvi.

\section{Acknowledgement}

The authors acknowledge Department of Human Nutrition and Dietetics, NIFSAT University Agriculture, Faisalabad, Pakistan, for providing facilities for the completion of this research work.

\section{References}

1. Ran-Chao W, Xin-Dong $\mathrm{H}$ \& Li-Ping $\mathrm{C}$ (2013). Finite-time stability of fractional-order neural networks with delay. Commun Theor Phys 60(2): 189.

2. Malkki Y (2001). Physiological properties of dietary fiber as key to physiological function. Cereal Foods World 46: 196-199.

3. Aune D, Chan DS,Lau R, Vieira R, Greenwood DC, KampmanE \&Norat $\mathrm{T}$ (2011). Dietary fibre, whole grains, and risk of colorectal cancer: systematic review and dose-response meta-analysis of prospective studies. $\mathrm{Br}$ Med J 10: 3436617.

4. Singh R, De S \& Belkheir A (2013). Avena sativa (oat), a potential neutraceutical and therapeutic agent: an overview. Crit Rev Food Sci 53: 126144.

5. Bao L, Cai X, Xu M \& Li $\mathrm{Y}$ (2014). Effect of oat intake on glycaemic control and insulin sensitivity: a metaanalysis of randomised controlled trials. Br J Nutr 112: 457-466.

6. Andersson KE, Immerstrand $\mathrm{T}$, Swärd K, Bergenståhl B, Lindholm MW, Öste R \& Hellstrand (2010). Effects of oats on plasma cholesterol and lipoproteins in 
C57BL/6 mice are substrain specific. $\mathrm{Br}$ J Nutr 103: 513-521.

7. Abnous K, Brooks SP, Kwan J, Matias F, Green-Johnson J, Selinger LB \& Kalmokoff M (2009). Diets enriched in oat bran or wheat bran temporally and differentially alter the composition of the fecal community of rats. J Nutr 139: 2024-2031.

8. Bordoloi R \& Ganguly S (2014). Extrusion technique in food processing and a review on its various technological parameters. Ind Jsrt 2(1): 1-3.

9. AACC (2000). Approved method of the american association of cereal chemists. $10^{\text {th }}$ Ed. American Association of Cereal Chemists; Minnesota (USA).

10. AOAC. 2006. Official Methods of Analysis of Association of Official Analytical Chemists International. $18^{\text {th }}$ Ed. AOAC Press; Arlington (USA).

11. Meilgaard MC, Civille GV \& Carr BT (2007). Sensory evaluation techniques. $4^{\text {th }}$ Ed. CRC Press; New York (USA).

12. Kim JD, Wang Y, Takagi T \& Yonezawa A (2011). Overview of genia event task in bionlpshared task 2011. In Proceedings of the Bio NLP Shared Task 2011 Workshop. ACL 7-15.

13. Alshatwi AA, Al-Obaaid MA, AlSedairy SA, Al-Assaf AH, Zhang JJ \&Lei KY (2010). Tomato powder is more protective than lycopene supplement against lipid peroxidation in rats. J Nutr Res 30(1): 66-73.

14. Kuo KL, Weng MS, Chiang CT, Tsai YJ, Lin-ShiauSY \&Lin JK (2005). Comparative studies on the hypolipidemic and growth suppressive effects of oolong, black, pu-erh and green tea leaves in rats. J Agric Food Chem 53: 480-489.

15. Maki KC, Galant R, Samuel P, Tesser J, Witchger MS, Ribaya-Mercado JD \& Geohas J (2007). Effects of consuming foods containing oat $\beta$-glucan on blood pressure, carbohydrate metabolism and biomarkers of oxidative stress in men and women with elevated blood pressure. Euro J Clin Nutr 61: 786-795.

16. Montgomery DC (2008). Design and analysis of experiments. $7^{\text {th }}$ Ed. John Wiley and Sons. Inc. Hoboken, NJ (USA), pp 162-264.

17. Kirk RS (1999). Composition and Analysis of foods.

18. Vázquez-Araújo L, Chambers E \& Cherdchu P (2012). Consumer input for developing human food products made with sorghum grain. J Food Sci 77: 384389.

19. Charlton KE, Tapsell LC, Batterham MJ, O'Shea J, Thorne R, Beck E \&Tosh SM (2012). Effect of 6 weeks' consumption of $\beta$-glucan-rich oat products on cholesterol levels in mildly hypercholesterolaemic overweight adults. Br J Nutr 107: 1037-1047.

20. Ho HV, Sievenpiper JL, Zurbau A, Mejia SB, Jovanovski E, Au-Yeung F \& Vuksan V (2016). The effect of oat $\beta$ glucan on LDL-cholesterol, non-HDLcholesterol and apoB for CVD risk reduction: a systematic review and metaanalysis of randomised-controlled trials. Br J Nutr116: 1369-1382. 